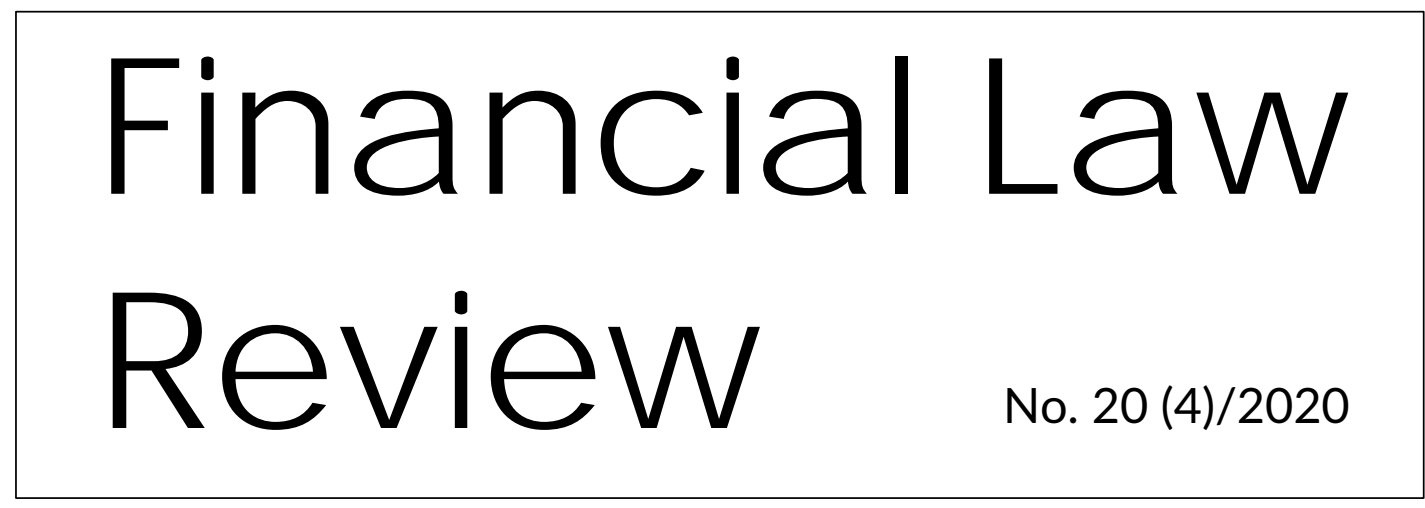

UNIVERSITY OF GDAŃSK • MASARYK UNIVERSITY • PAVEL JOZEF ŠAFÁRIK UNIVERSITY • UNIVERSITY OF VORONEZH http://www.ejoumals.eu/FLR

\title{
LIMITATION OF PUBLIC DEBT ON THE VERGE OF FINANCIAL CRISIS
}

\begin{abstract}
The foretaste of the financial crisis raises the question of the functioning, application and enforcement of measures to ensure sound and sustainable public finances. The limitation of public debt was enshrined in law in the Czech legal system in 2017, and in April of this year one of the established fiscal rules was amended. The aim of this article is to critically analyze the adjustment of the public debt limitation that has been undertaken in the context of the current crisis caused by the spread of COVID-19. The introduction of the article will describe the European and Czech context of the limitation of public debt and setting budgetary responsibility. Subsequently, the article briefly summarizes the effects of the coronavirus crisis on the implementation of the state budget and, consequently, the justification for the legislative change of the set fiscal rule.

The methods used in the article are mainly the method of literary research relevant sources, the method of description of the limitation of the public debt regulation in European union and in passages describing the current state of budgetary responsibility rules. Method of evaluation

\footnotetext{
* PhD Candidate for Financial Law, Department of Financial Law and Economics, Faculty of Law, Masaryk University in Brno, Czech Republic. Author specializes in issues of budgetary discipline and responsibility, financial control and audit. Author shares her experience mainly through the training of employees in public administration and several papers based on research presented at national and international conferences. Contact email:vuongova@gmail.com.
} 
appears in the parts of the work evaluating the legislative adjustments to budgetary responsibility rules due to the coronavirus crises.

Key words: budgetary responsibility; sound public finances; fiscal rules; expenditure rule; debt rule.

JEL Classification: E62, H68

\section{Introduction}

The financial crisis in 2008 triggered a wave of discussions and, subsequently, new rules to ensure sound and sustainable public finances. Today, we are facing a crisis that is still more associated with the adjective 'coronavirus' than the adjective 'financial', but it is certainly no less of a threat to sustainable and sound public finances than crises in 2008. Of course, with the expectation of an economic recession, the door is opened to discuss public debt and fiscal rules, which should lead to better budgetary responsibility. To begin with, fiscal rules can be defined using Kopits and Symanski's definition, according to which the fiscal rule is a long-term constraint on fiscal policy, usually defined in terms of some indicator of aggregate fiscal behaviour. The rules at discretion cover the aggregate fiscal indicator, such as the government budget deficit, borrowing, debt, or the main components of the enumerated variables, often expressed as a numerical ceiling or objective in proportion to GDP [Kopits, Symansky 1998: 2]. Fiscal rules are a set of rules that should help stabilize public finances and prevent growth of public debt. These include, for example, the balanced budget rule, the debt rule, the expenditure rule and the revenue rule [Lotko, Koziel 2016: 163-173].

In the Czech Republic, the principle of balanced state budget, which expresses the traditional requirement for equality of the revenue and expenditure side of the budget, can be considered obsolete. The balance of the state budget has simply been considered a goal of budgetary policy in the past. "In its pure form, this principle meant that the state budget for each budget year must be balanced, ie the revenues and expenditures of the state budget had to be identical. This was related to the fact that the principle of completeness of the state budget was consistently enforced, ie the postulate that all state revenues and expenditures should be included in one (state) budget. This principle is already overcome today, as there are a number of public budgets" [Boháč 2010]. The principle of balanced state budget is today replaced by the principle of long-term balanced budget and the application of the fiscal rule of balanced budget. According to the principle of long-term balance of the budget, the public budget does not have to be balanced in a given budget year, but only in the long run. It should be mentioned that in the Czech Republic, the state budget has always been made as 
deficit since 1998. On the contrary, the principle of budgetary balance must always be followed when drawing up the budget of the European Union.

Debt, expenditure and revenue fiscal rules exist in various modifications depending on the economic development of a country. An integral role is played by the European Union, which has been setting trends in this area since its inception. These trends arrived in the Czech Republic only a few years ago.

\section{European dimension}

According to the Treaty on the Functioning of the European Union, the Member States retain sovereignty over the European Union in budgetary policies. However, the Union demands economic policy coordination in order to prevent a further economic crisis and threats to monetary stability in the euro area. The fundamental principle on which the coordination of economic policies in the European Union is based, is compliance with the principle of sound public finances and monetary conditions and a sustainable balance of payments. This principle is enshrined in Article 119 (3) of the Treaty on the Functioning of the European Union. Other excessive deficit commitments results from Article 126, according to which Member States undertake to avoid excessive government deficits. The development of the budgetary situation and of the stock of government debt in the Member States with a view to identifying gross errors is monitored by the European Commission.

Respect for the principle of sound public finances is ensured by the Stability and Growth Pact ("the Pact"), which was established in 1997 and amended in 2005 and 2011. The Pact was based on the premise that "budgetary discipline is an essential element of macroeconomic stability and fiscal rules strengthen the credibility of economic policy" [Marková 2005]. The main requirement of the Pact is that Member States achieve and maintain the mediumterm budgetary objectives they have agreed on. In the event of a risk of a significant deviation from its gradual achievement, the European Commission will issue a warning to the State concerned and the Council may adopt a recommendation and take corrective action to the Member State. Financial sanctions can only be imposed on countries that are members of the euro area. A non-euro area country is in danger of being suspended from drawing on European Union funds. The last amendment in 2011, which responded to the financial crisis, approved the expenditure fiscal rule. According to the expenditure rule, the rate of expenditure growth must not exceed the medium-term growth rate of potential output in individual years. Countries whose debt-to-GDP ratio exceeds $60 \%$ have an 
obligation to reduce their debt levels. The average rate of decline of the debt to GDP is determined as $1 / 20$ of the difference between the actual level of the debt share in GDP and $60 \%$ of GDP. In some countries a certain limitation of public debt already existed (Poland, Germany), in many it was enshrined in legislation following the amendment of the Pact.

The 2011 legislative package, which was a response to the financial crisis, also brought the Council Directive 2011/85/EU of 8 November 2011 on requirements for budgetary frameworks of the Member States. The Directive requires Member States to have a credible and efficient medium-term budgetary framework, including a fiscal planning horizon of at least three years, and to have comprehensive, consistent and transparent budgetary accounting and statistical reporting systems.

So far, the last act at the level of the European Union is the Treaty on Stability, Coordination and Governance in Economic and Monetary Union, signed in 2012 by 25 member states of the European Union, at that time only the signing of the Czech Republic and Great Britain was missing. This Treaty aims to strengthen budgetary responsibility and strengthen the coordination of the economic policies of the Member States of the European Union. The Treaty obliges signatories to incorporate into national law the rule of balanced general government budgets, meaning that the annual structural balance of the general government is at its country-specific medium-term objective, as defined in the revised Stability and Growth Pact, with a lower limit of a structural deficit of 0,5\% of the gross domestic product at market prices.

\section{The budgetary responsibility rules in Czech Republic}

The Czech Republic has started the national regulation of the limitation of public debt and budgetary responsibility only in 2017 , when the Act on Budgetary Responsibility entered into force. This step followed the initiation of infringement proceedings of Treaty on the Functioning of the European Union for non-transposition of Council Directive 2011/85/EU of 8 November 2011 on requirements for budgetary frameworks of the Member States into national legislation. The obligation to bring into force the provisions necessary to comply with this Directive was laid down by 31 December 2013. Of the four Visegrad Group countries, the Czech Republic was the last to limit public debt. The leader in this area was Poland, which captured the limitation of public debt and non-exceeding of the debt limit of $60 \%$ of GDP in the constitution and debt zones in the law on public finances. Hungary followed a similar approach under the new Hungarian constitution, 
which entered into force in 2012. Slovakia, as the only Visegrad Group country member of the euro area, adopted a constitutional law on budgetary responsibility at the end of 2011 , setting a constitutional limit on public debt, including the consequences of exceeding it [Koziel 2014: 26-33].

The rules of budgetary responsibility were thus adopted by the Czech Republic last, and moreover only in the form of an ordinary law, although the government originally submitted a draft constitutional law to parliament. The reasons for the delay were partly caused by the government crisis and the subsequent resignation of the government in 2013. The new government did not have a sufficient negotiating position to approve the constitutional law and failed to get enough votes for the constitutional majority. The longstanding discussion on the "financial constitution" ended with the adoption of the law on budgetary responsibility, which introduced the new principles strengthening the transparency of public finances into the Czech legal system. Furthermore, the law became a promise of sound and long-term sustainable public finances and provision of sufficient room for decision-making in the implementation of budgetary and fiscal policy [The explanatory memorandum to the Act on Budgetary Responsibility Rules].

The rules on budgetary responsibility affect the whole sector of public institutions based on the statistical definition defined by DG Eurostat. Comprehensive institutional coverage ensures the implementation of fiscal policy not only at the level of the state and its managed organizations, but also at the level of territorial self-governing units, public universities, public research organizations or health insurance companies. Transparency of public finances is strengthened in the new rules of budgetary responsibility by the introduction of the obligation to provide the public in a timely and open manner with all relevant information on the management of public institutions. This transparency strengthens credibility and acts preventively to ensure budgetary discipline and responsibility. From the numerical fiscal rules, the expenditure rule and the debt rule are introduced, which should ensure the fulfilment of the above-mentioned goal of the Act on Budgetary Responsibility.

The expenditure rule acts as an automatic correction mechanism to reach the mediumterm budgetary objective. The total expenditure of the public sector according to this rule must correspond to the sum of:

- medium-term budgetary objective of no more than 1\% of GDP,

- cyclically-adjusted forecasted total revenue of public institutions, 
- negative values of one-off and temporary operations expressed in aggregate as the difference between these operations on the revenue and expenditure side,

- the amount of expenditure allowed by the escape clause, and

- negative value of one third of the correction component, which exceeded $2 \%$ of GDP.

This rule takes into account the rules of the European Union expressed in the Stability and Growth Pact, for the short- and medium-term balance of the general government sector and the growth of its expenditure.

The debt rule introduces the obligation to apply measures leading to a long-term sustainable state of public finances if the debt of the public sector, after deducting the cash reserve in the financing of government debt, amounts to at least $55 \%$ of nominal GDP. The measures consist in the obligation of the government to prepare and submit a proposal and a medium-term outlook of the state budget and budgets of state funds, which lead to a long-term sustainable state of public finances and to submit a balanced budget of health insurance companies. In the event of exceeding the set limit, territorial self-governing units must approve their budget for the following year as balanced or in surplus. Other public institutions may not, after a period of debt of at least $55 \%$ of GDP, enter into new commitments under contracts leading to increase of public sector debt for more than one calendar year, with the exception of commitments relating to projects cofinanced by the European Union budget or commitments necessary to comply with a court or public authority. These measures shall not apply in the event of a significant deterioration in economic development, a state of emergency or a state of war, during emergency measures announced by the government to increase the state's defences due to deteriorating security and high disaster relief expenditure.

Special debt rule, resp. the obligation is set for territorial self-governing units. If the debt of a territorial self-governing unit exceeds $60 \%$ of the average of its income for the last 4 years, it is obliged to reduce the debt by at least $5 \%$ of the difference between the current amount of debt and $60 \%$ of the average of its income for the last 4 years. Failure to comply with this obligation may lead to the suspension of the transfer of tax revenue in the amount of $5 \%$ of the difference between the amount of the debt of the territorial selfgovernment unit and $60 \%$ of the average of its income for the last 4 years. The fiscal rule set in this way is intended to lead local and regional authorities to gradually repay their debts, not to accumulate them. It is possible to state a certain disproportionality of the approved measures for individual levels of public institutions. Local and regional authorities are obliged to reduce their debt under the threat of suspension of part of tax revenues, 
while the central government is "only" obliged to propose budget adjustments that lead to a long-term sustainable state of public finances.

In addition to the described fiscal rules, the Czech Fiscal Council was established by the Act on Budgetary Responsibility. The Czech Fiscal Council is to be an independent body operating in the field of fiscal and budgetary policy. The main tasks of the Czech Fiscal Council include monitoring and evaluating compliance with fiscal rules, ascertaining and declaring government debt, monitoring the economic development of the public institutions sector and preparing a report on the long-term sustainability of public finances. Until the outbreak of the coronavirus crisis, the Czech Fiscal Council stated compliance with the expenditure and debt rules of budgetary responsibility.

The last step that the Czech Republic has taken to move closer to European requirements for setting budgetary responsibility rules was the signing of the Fiscal Compact. The Fiscal Compact, or the Treaty on Stability, Coordination and Governance in the Economic and Monetary Union, was ratified by the Czech Republic as the last member state of the European Union six years after its entry into force in 2019.

\section{Amendment to Act on Budgetary Responsibility Rules}

The forecasts used to base the 2020 budget did not anticipate a crisis related to the spread of coronavirus disease. Of course, this fact is not only a problem of the Czech Republic, but of all the countries affected by this crisis. Before the outbreak of the crisis, the Czech Republic reported for the sixth year in a row a reduction in government debt in ratio to GDP from 30.5\% to 29\% [Quarterly Report on the Management of the State Debt of the Czech Republic - 1st half of 2020]. A significant drop in economic activity, a reduction in state budget tax revenues, an increase in expenditures, all in the face of uncertainty about the further development of the crisis, led to three amendments to the State Budget Act for 2020 in the Czech Republic. The state budget deficit was gradually increased from the original CZK 40 billion to CZK 500 billion. The fall in tax revenues and social security contributions was caused by measures aimed at supporting natural and legal persons in the form of tax relief and social and health insurance relief. The expenditure side of the budget was burdened by purchases of personal protective equipment, increased state payments for state insured persons, support in the employment program, support in, but also ongoing government activities in increased investment activity or remuneration of teachers or health workers. To cover the crisis deficit of the state budget and the pre-financing of this year's state debt repayments, a historically record issue of government bonds was carried 
out and the state debt increased by 516.7 billion CZK [Quarterly Report on the Management of the State Debt of the Czech Republic - 1st half of 2020].

Last but not least, it is necessary to point out the use of the current situation to promote the political goals of the Czech government, especially in the social and tax area. A legislative process is currently underway in Parliament to abolish the acquisition of immovable property tax for real estate acquired since December 2019, with the pretext of supporting the real estate market. Although the abolition of the tax has been widely discussed in the past and proposed in times of economic prosperity, the government has rejected the abolition precisely with reference to disproportionate budget intervention. Furthermore, a one-off contribution at the end of the year for pensioners in the amount of CZK 5,000 was promised in the media at a time when the economic impacts caused by the current crisis are not known. These are just a few examples of government measures with a major impact on the state budget and public debt, which could be considered be the society as the manifestation of political populism and a resignation to responsible budgetary policy.

The above facts have, of course, opened a discussion on the set rules of budgetary responsibility. The legislative change did not take long. With a direct reference to the serious risks caused by the coronavirus pandemic and the unprecedented nature of the current global crisis, the government presented a proposal to amend the Act on Budgetary Responsibility Rules to parliament in early April this year as part of a declared state of emergency. The brief draft of the amendment was discussed expeditiously, and although it was rejected by the Senate, it was finally approved during the month of April.

Although the original budgetary responsibility rules provide exceptions for emergencies, the loosening of fiscal rules would only apply for 2020. In 2021, the government would have to set fiscal policy significantly restrictively. According to the explanatory memorandum to the amendment, the necessary fiscal consolidation of expenditures would amount to up to CZK 150 billion and it is thus not possible to respond to the current crisis with the traditional system of fiscal rules. The negative effects of the recession in 2020 and beyond are expected to shift to the following years and the real threat of a sharp increase in the tax burden or a significant reduction in spending is expected. According to the approved amendment to the Act on Budgetary Responsibility, a 7-year fiscal space will be created by increasing the maximum allowable values of structural deficits from $1 \%$ of GDP to 4\% of GDP for 2021 and in subsequent years to a year-on-year improvement in the general government balance, at least to the extent of 0.5 percentage point. In this way, a gradual approach to the current level of the medium-term budgetary objective and its 
safe achievement in 2028 should be ensured without jeopardizing the economy with an excessive one-off negative fiscal shock.

Reference should also be made on this spot to the Communication from the Commission to the Council on the activation of the General Escape Clause of the Stability and Growth Pact. The Commission anticipates a decline in economic activity in 2020 comparable to that of the financial crisis in 2008. Based on this forecast, both the Commission and the Council have already stated that full flexibility under the Stability and Growth Pact will apply to coronavirus crisis measures. The Stability and Growth Pact contains two clauses which allow for the application of appropriate budgetary measures in exceptional circumstances - unusual events clause and general escape clause. The activation of the general escape clause was announced on 17 March 2020 and the above-mentioned communication confirmed in writing that the conditions for its activation had been met for the first time since its introduction in 2011.

Intervention into the established fiscal rule set in Act on Budgetary Responsibility Rules in the form of "escape provisions" can be viewed critically or, conversely, with faith in the expert assessment of the government in the context of macroeconomic forecasts and further developments in the crisis. From a critical point of view, the adjustment of fiscal rules in the event of the first economic crisis since its introduction is undesirable and testifies to the inadequacy of the set system from the very beginning. Budgetary responsibility rules should also be applicable to specific situations such as this coronavirus crisis and should not be adapted to it by changing paragraphs. The original law on budgetary responsibility already allows for a sufficient response to extraordinary situations causing economic problems, for example in the form of one-off and transitional measures, so the changes made can be considered redundant. Criticism may continue in that the government's claims in the explanatory memorandum to the amendment of the Act are not substantiated and the possibility of greater state indebtedness could be limited to less than 7 years. In addition, there is a risk of limiting control over public spending and abusing the open space for government indebtedness not only to address the economic impact of the coronavirus crisis, but also to pursue political goals. The introduction of restrictive measures and the "tightening of belts" may be perceived negatively in the eyes of the general public and may subsequently have an effect on electoral preferences. In an effort to prevent this effect, it is therefore appropriate to fear that the loosening of fiscal rules is a resignation to the responsible approach of political representatives in matters of public debt to future generations. In a borderline case, we can even talk about the nonfunctioning of fiscal rules, as hinted by Křepelka: "Political and economic power will eliminate 
the legal framework. The rules are simply being overlooked. Or they will be used to abuse the exceptions... Penalties for non-compliance are lacking... Under these circumstances, debt brakes are only reassuring the part of the public that emphasizes sound public finances" [Křepelka 2013: 82].

The Czech Fiscal Council also took a critical stance on the amendment to the Act on Budgetary Responsibility Rules within the legislative process and in its written statement. Although the Czech Fiscal Council agreed that the current situation calls for extraordinary measures, it believes that the $1 \%$ limit on the structural balance does not limit the government's fiscal space and there is therefore no reason to increase it. Although the health of citizens is currently a priority, it does not consider such a loosening of fiscal policy necessary over the next seven years.

It is also necessary to add to the criticism the fact that the amendment was not consulted in any way with the Czech Fiscal Council.

If we do not look at the amendment to the Act on Budgetary Responsibility Rules from a critical point of view, we can perceive this step positively as an effort by the executive and legislative power to take preventive measures to help the state get out of the predicted economic crisis. The amendment to the law thus becomes a tool for further decisionmaking in the direction of the state's fiscal and budgetary policy. However, with this conclusion, we accept the criticism of setting fiscal rules, which was expressed, for example, by Holländer. He described the introduction of rules of budgetary responsibility "as an expression of scepticism about society's ability to draw conclusions from previous, flawed budgetary policies, about the ability of the political class to manage the public sector sensibly and responsibly" [Holländer 2013: 52]. At the same time, it would be a matter of rejecting the depoliticization of budgetary and fiscal policy decisions in the form of fiscal rules. I consider such a view on setting exceptions to the rules of budgetary responsibility, to be exaggerated and I am inclined to rational criticism, which could be supported by society in particular by drawing consequences in the forthcoming elections.

\section{Conclusion}

The setting and functionality of fiscal rules cannot be judged only by the results in times of economic growth. The coronavirus crisis has prepared a burdensome test to verify the readiness of the European Union countries to maintain sound and sustainable public finances, as committed in its national legislation and international agreements. After many years of efforts, the Czech Republic joined the family of European states legislating the 
public debt limit in 2017 and, after only three years, proceeded to amend the set fiscal rules. The question thus arises whether the fiscal rules are set solely to meet the transposition obligation or are the result of a genuine effort to enshrine the principle of sound public finances. The aim of this article was to subject to critical analysis the adjustment of the limitation of public debt in the Czech Republic, which was undertaken in connection with the current crisis caused by the spread of coronavirus. It is definitely necessary to take the side of the criticism, which considers premature to discount from the set limits. On the other hand, it is necessary to point out the fact that the Czech Republic is far from reaching the average level of indebtedness in the European Union. At the end of the first quarter of 2020, when measures against the spread of coronavirus began to be introduced, the Czech Republic had the 4th lowest government debt-to-GDP ratio. A real assessment of crisis management in terms of fiscal policy will only be possible over time. 


\section{References}

Boháč, R.: Zásada vyrovnanosti veřejných rozpočtů $v$ České republice $v$ první dekádě 21 . Století [The principle of balanced public budgets in the Czech Republic in the first decade of the 21st century], Acta Universitatis Carolinae - luridica 4, 2010.

Holländer, P: Finanční ústava aneb defenzivní konstitucionalismus současné doby [Financial constitution or defensive constitutionalism of the present time], in: Šimíček F: Finanční ústava [Financial constitution], Brno: Masarykova univerzita, 2013.

Kopits, G.; Symansky, S. Fiscal Policy Rules. Washington: International Monetary Fund, 1998,

Koziel M.: Limitace veřejného zadlužování v zemích Visegrádske čtyřky [Limitation of Public Debt in Vesegrad Group countries], Jurisprudence, no 3/2014.

Křepelka, F: Čas dluhových brzd v Evropské unii [The time of debt brakes in European union], in: Šimíček F: Finanční ústava [Financial constitution], Brno: Masarykova univerzita, 2013.

Lotko E., Koziel M.: Polské stabilizující výdajové pravidlo jako inspirace pro českého zákonodárce [Polish Stabilizing Expediture Rule as an Inspiration for Czech Lawmaker], Časopis pro právní vědu a praxi [Journal of Jurisprudence and Legal Practice], Vol XXIV, no 2/2016.

Marková, H.: Role Paktu stability a růstu v rozpočtovém hospodaření [The role of the Stability and Growth Pact in budgetary management], International and Comparative Law Review, No. $14 / 2005$.

\section{Legal Acts}

Act no. 23/2017 Coll., on Budgetary Responsibility Rules, as amended.

Council Regulation (EC) $1466 / 97$ on the strengthening of the surveillance of budgetary positions and the surveillance and coordination of economic policies (the preventive arm of the Stability and Growth Pact).

Council Regulation (EC) 1467/97 on speeding up and clarifying the implementation of the Excessive Deficit Procedure (the corrective arm of the Stability and Growth Pact).

Council Regulation (EC) 479/2009 on the application of the Protocol on the EDP.

Directive 2011/85/EU on requirements for budgetary frameworks of the Member States.

Regulation (EU) No 1173/2011 on the effective enforcement of budgetary surveillance in the euro area - sanctions regulation.

Regulation (EU) No 1174/2011 of 16 November 2011 on enforcement measures to correct excessive macroeconomic imbalances in the euro area.

Regulation (EU) No 1176/2011 of 16 November 2011 on the prevention and correction of macroeconomic imbalances.

The Treaty on the Functioning of the European Union (consolidated version - Offcial Journal C36, 26/2012).

Treaty on Stability, Coordination and Governance in Economic and Monetary Union.

\section{Other official documents}

Communication from the Commission to the Council on the activation of the General Escape Clause of the Stability and Growth Pact.

Available at: https://op.europa.eu/en/publication-detail/-/publication/ed5a2bf5-6b65-11eab735-01aa75ed71a1/language-en, accessed: $31^{\text {st }}$ August 2020.

Quarterly Report on the Management of the State Debt of the Czech Republic - 1st half of 2020. Available at: https://www.mfcr.cz/cs/verejny-sektor/rizeni-statniho-dluhu/publikace-aprezentace/dluhove-portfolio-ctvrtletni-informace/2020/ctvrtletni-zprava-o-rizeni-statnihodluh-39006, accessed: $31^{\text {st }}$ August 2020.

The explanatory memorandum to the Act no. 23/2017 Coll., on Budgetary Responsibility Rules. Available at: https://www.psp.cz/sqw/sbirka.sqw?.cz $=23 \& r=2017$, accessed: $31^{\text {st }}$ August 2020.

The explanatory memorandum to the Act no. 207/2020 Coll, amending the Act no. 23/2017 Coll., on Budgetary Responsibility Rules.

Available at: https://www.psp.cz/sqw/sbirka.sqw?cz=207\&r=2020, accessed: $31^{\text {st }}$ August 2020. 
Statement of the Czech Fiscal Council concerning the government's proposal to amend act no. 23/2017 coll. On budgetary responsibility rules.

Available at: https://unrr.cz/en/statement-of-the-czech-fiscal-council-concerning-thegovernments-proposal-to-amend-act-no-23-2017-coll-on-budgetary-responsibility-rules/, accessed: $31^{\text {st }}$ August 2020. 